\title{
SUSTAINABILITY MANAJEMEN MASJID MELALUI PENDAMPINGAN REMAS BAITURRAHMAN BAYEMAN ARJASA SITUBONDO
}

\author{
Hariyanto \& Lilit Biati \\ Universitas Ibrahimy Situbondo \\ IAI Darussalam Blokagung Banyuwangi \\ hariyantolppm@gmail.com \\ lilitbiati@gmail.com
}

\begin{abstract}
Setrategis mosque youth as agents in the empowerment of the people need to be equipped with the knowledge and skills needed, for example, the mosque youth activists also need to pursue knowledge of journalism and Kewirausahaan.Hal it was important to strengthen propaganda and empowerment umat.Dua that knowledge can be a means of propaganda, as well as increasing HR Teen mosque so that they can be independent. The mosque is an instrument of empowerment of people who have a very strategic role in improving the quality of society. However, it should be backed by good management of the mosque management and integrated. The mosque is used as a community center for the reason that since the time of the Prophet mosque became the center of people's empowerment are not limited only role is the implementation of compulsory worship such as prayer.
\end{abstract}

Keyword: Komunitas, Pengabdian,Community Based Research

\section{PENDAHULUAN}

Gambaran umum kondisi subyek dampingan, bahwa Kabupaten Situbondo samapai saat ini merupakan salah satu daerah miskin di Propinsi Jawa Timur karena pendapatan asli daerah yang rendah dan banyak penduduk yang hidup dibawah garis kemiskinan. Pada tahun 2001 jumlah penduduk miskin adalah 173.357 jiwa. Jumlah tersebut pada tahun 2004 mengalami peningkatan menjadi 177.624 jiwa atau mengalami kenaikan 2,46\%. Hal itu disebabkan oleh kondisi perekonomian yang belum sepenuhnya kembali normal.

Desa Bayeman meruapakan desa yang terletak di kecamatan Arjasa kabupaten Situbondo Provinsi Jawa timur. Desa bayeman tergolong paling kecil di kecamatan Arjasa bahkan di kabupaten Situbondo. Kondisi tanah, Datar, Ketinggian \pm 50/100 m dari Permukaan Laut. Batas-batas Desa Bayeman. DARI Utara : Desa Ketowan (Kec.Arjasa) Timur : Desa Sopet (Kec.Jangkar) Selatan : Perhutani / Desa Kayumas (Kec.Arjasa) Barat : Desa Jatisari (Kec.Arjasa). Desa Bayeman Terdiri dari dua dusun: 
Dusun Krajan : 2 Rw, 5 RT Dusun Dawuan : 2 Rw ,6 RT.

Berdasarkan Data Administrasi Pemerintahan Desa, jumlah penduduk yang tercatat secara administrasi, jumlah total 1.809 jiwa. Dengan rincian penduduk berjenis kelamin laki-laki berjumlah 861 jiwa, sedangkan berjenis perempuan berjumlah 948 jiwa. Survei Data Sekunder dilakukan oleh Fasilitator Pembangunan Desa, dimaksudkan sebagai data pembanding dari data yang ada di Pemerintah Desa. Survei Data Sekunder yang dilakukan berkaitan dengan data penduduk pada saat itu.

Tingkat pertumbuhan penduduk Desa Bayeman diambil berdasarkan tingkat pertumbuhan rata-rata penduduk Kecamatan Arjasa selama lima tahun rata-rata pertumbuhannya sebesar $5 \%$ (sumber : Kecamatan dalam angka).

\section{METODE}

Metode Pendekatan PAR dilakukan dengan proses pemetaan awal yang juga melibatkan pihak-pihak terkait dalam pendampingan ini, maka kegiatan pendampingan pada Penguatan Manajemen Organisasi Masjid Melalui Parsitisipasi Remaja Masjid Baiturrahman Desa Bayeman Kec. Arjasa Kab. Situbondo Yang Dilakukan Pendamping Antara Lain:

melakukan focus group discussion (FGD) dengan pengurus takmir masjid dan remaja masjid menjadi rujukan dalam proses pelaksanaan pengabdian ini.

Membangun komunikasi dengan komunitas dengan remaja masjid Baiturrahman desa Bayeman kec. ARJASA kab. Situbondo. di tahapan ini tim merancang kegiatan yang menyesuaikan degan topik permasalahan yang ditemukan selama proses pemetaan awal, sehingga narasumber pendamping dapat leluasa menyampaikan materi sesuai dengan persoalan yang dihadapi oleh remaja masjid dalam ikut serta dalam kegiatan organisasi masjid.

\section{HASIL DAN DISKUSI}

Prespektif Budaya Masyarakat di Desa Bayeman sangat kental dengan budaya Islam. Hal ini dapat dimengerti karena hampir semua desa di Kabupaten Situbondo sangat kuat terpengaruh pusat kebudayaan Islam yang tercermin dari keberadaan Pondok PesantrenPondok Pesantren yang ada di Situbondo.

Dari latar belakang budaya, kita bisa melihat aspek budaya dan sosial yang terpengaruh dalam kehidupan masyarakat. Didalam hubungannya dengan agama yang dianut misalnya Islam 
sebagai agama mayoritas dianut masyarakat, dalam menjalankannya sangat kental dengan tradisi budaya Islam.

Perspektif budaya masyarakat di Desa Bayeman masih sangat kental dengan budaya ketimurannya. Dari latar belakang budaya, kita bisa melihat aspek budaya dan sosial yang berpengaruh dalam kehidupan masyarakat. Didalam hubungannya dengan agama yang dianut misalnya, Agama Islam sebagai agama mayoritas dianut masyarakat, dalam menjalankan sangat kental dengan tradisi budaya ketimuran.

Tradisi budaya ketimuran sendiri berkembang dan banyak dipengaruhi ritual-ritual agama atau kepercayaan masyarakat sebelum Agama Islam masuk. Hal ini menjelaskan mengapa peringatan-peringatan keagamaan yang ada dimasyarakat, terutama Agama Islam dipeluk mayoritas masyarakat, dalam menjalankannya muncul kesan nuansa tradisinya. Contoh yang bisa kita lihat adalah peringatan tahun baru Hijriyah dengan melakukan do'a bersama dimasjid dan mushalla-mushalla.

Contoh yang lain adalah ketika menjelang Ramadlan masyarakat berbondong-bondong mendatangi kuburan/makam orang tuanya maupun kerabat dan para leluhurnya untuk dibersihkan dan setelah itu melakukan tahlilan bersama dimasjid dan mushalla kemudian makan bersama saat itu juga. Contoh yang lain lagi ketika peringatan Maulid Nabi Muhammad SAW, yang diperingati di masjid-masjid dan mushalla dan ada juga yang diperingati dirumah warga yang kehidupannya sudah diatas cukup. Biasanya pada peringatan ini masyarakat menyediakan berbagai macam hidangan yang berupa buah-buahan dan makanan serta membuat nasi tumpeng dll.

Secara individual didalam keluarga masyarakat Desa Bayeman, tradisi ketimuran dipadu dengan Agama Islam juga masih tetap dipegang. Tradisi ini dilakukan selain sebagai kepercayaan yang masih diyakini sekaligus digunakan sebagai media untuk bersosialisasi dan berinteraksi di masyarakat. Misalkan, tradisi mengirim do'a untuk orang tua atau leluhur yang dilakukan dengan mengundang para tetangga dan kenalan yang istilah populernya diberi nama kouleman / kondangan. Kolonan ini biasanya dilakukan mulai dari satu sampai tujuh harinya keluarga yang ditinggal mati, yang disebut tahlilan. Selanjutnya hari ke empat puluh/pa'pholo, 
hari ke seratus/nyatos dan seribu harinya/nyebuh perhitungan tanggal kegiatan menggunakan penanggalan jawa.

Bersyukur kepada Allah SWT, karena dikaruniai anak pertama pada tradisi masyarakat Desa Bayeman juga masih berjalan disebut pelet betteng ketika kandungan ibu menginjak usia 7 bulan dimana suami istri keluar secara bersamaan kehalaman rumah untuk dimandikan kembang dengan memakai cewok dari batok kelapa dan pegangannya memakai pohon beringin kemudian setelah selesai cewok tersebut dilempar keatas genting oleh mbah dukunnya, jika posisi cewok tersebut terlentang maka ada kemungkinan anaknya perempuan, tetapi jika posisinya sebaliknya maka diyakini kalau anaknya akan lahir laki-laki.

Tetapi yang harus diwaspadai adalah muncul dan berkembangnya pemahaman keyakinan terhadap agama ataupun kepercayaan tidak berakar dari pemahaman terhadap tradisi dan budaya masyarakat yang sudah ada. Hal ini mulai mengakibatkan munculnya kerenggangan sosial dimasyarakat dan gesekan antara masyarakat. Meskipun begitu sudah ada upaya untuk mengurangi gesekan yang ada di masyarakat dengan cara persuasif.

Aspek pemberdayaan masyarakat (Community Empowering) masyarakat local merupakan prioritas dalam pengembangan sosial budaya yang ada di masyarakat. Proses pemberdayaan masyarakat yang utama adalah mengembangkan dan mempertahankan setiap partisipatif masyarakat dalam proses pembangunan.

Pengembangan pariwisata di wilayah Desa Bayeman masih belum memanfaatkan potensi sumber daya alam setempat. Sedangkan potensi yang ada dan berpeluang dikemangkan sebagai obyek wisata adalah wisata alam Bayeman.

\section{Pengetian Remaja Masjid}

Masjid merupakan instrumen pemberdayaan umat yang memiliki peranan sangat strategis dalam upaya peningkatan kualitas masyarakat. Namun hal itu harus didukung oleh menejemen pengelolaan masjid yang baik dan terpadu. Masjid digunakan sebagai pusat kegiatan dengan alasan bahwa sejak zaman Rasulullah masjid menjadi pusat pemberdayaan umat yang tidak terbatas perannya hanya pelaksanaan ibadah wajib seperti shalat. Di zaman Rasulullah masjid bisa berfungsi sebagai halaqoh, yakni untuk mendiskusikan berbagai permasalahan umat bahkan menjadi bagian dari perumusan kegiatan politik. Peran masjid menjadi dinamis dan 
berfungsi mendorong tumbuhkembangnya keberdayaan umat. Mengacu pada tradisi kenabian tersebut sebenarnya masjid dapat berkembang lebih luas menjangkau pengayaan sumberdaya umat melalui bentuk-bentuk kegiatan yang bersinergi antara praktik-praktik keberagamaan dan kehidupan umat di sekitar masjid. ${ }^{1}$

Dilihat dari segi fungsinya, sebenarnya masjid tidak hanya merupakan tempat atau sarana melaksanakan ibadah shalat semata. Masjid juga bisa berfungsi sebagai pusat pemberdayaan (empowering) berbagai aspek kehidupan masyarakat sebagaimana yang telah dicontohkan oleh Rasulullah SAW dalam kehidupanya.

Disamping itu juga, fungsi masjid dikaitkan dengan implementasi ajaran Islam meliputi fungsi imaniyah mendekatkan diri kepada Allah dengan berteologi yang benar, fungsi ubudiyah menjalankan ritual sesuai aturan agama, fungsi mu'amalah memberdayakan umat dalam berbagai aspek kehidupan, fungsi adab mu'asyarah bersosialisasi dan kerjasama yang harmonis dalam kehidupan, dan fungsi akhlaq atau berperilaku yang baik untuk membangun peradaban. ${ }^{2}$

\section{Fungsi Masjid}

Untuk mempertegas fungsi dasar masjid tersebut, setidaknya dapat dikembangkan menjadi beberapa fungsi secara lebih rinci sebagai berikut:

a. Fungsi keagamaan; untuk melaksanakan berbagai ritual keagamaan, yakni shalat, pembagian zakat, manasik haji, memberi fatwa dan lain-lain

b. Fungsi sosial, untuk tempat berinteraksi, menerima dan memahami orang lain, baik secara individu maupun secara orang lain

c. Fungsi psikologi, untuk memberi rasa aman dan kebersamaan serta memupuk persatuan dan rasa optimisme

d. Fungsi edukasi dan berdakwah, sebagai tempat pelaksanaan berbagai pendidikan, diantaranya pelaksanaan TPQ, pendalaman pemahaman ilmu sosial-ekonomi dan eksak,pendidikan moral dan perpustakaan

${ }^{1}$ Mufidah Ch, dkk, Menjadi Sejahtera \& Mandiri Bersama Posdaya Masjid Kabupaten Malang (LP2M-UIN Maling Press, 2014), hlm.3.

${ }^{2}$ Ahmad Sarwono, Masjid Jantung Masyarakat (yogyakarta: Izzan Pustaka, 2003), 4.

\section{Vol. 1 No. 1, April 2019


e. Fungsi politik; untuk perdamaian, tempat mengatur strategi perang menerima delegasi dan memusyawarahkan urusan kemasyarakatan dan kenegaraan

f. Fungsi pengobatan fisik dan mental

g. Fungsi peradilan

h. Fungsi komunikatif, yakni tempat untuk mengkomunikasikan informasi atau musyawarah hal-hal yang berkait dengan pemberdayaan masyarakat

i. Fungsi estetis, tempat pelaksanaan dan pengembangan seni. ${ }^{3}$

Menurut Nazarudin Umar, Rasulullah SAW tidak hanya menjadikan masjid sebagai tempat pelaksanaan ibadah khusus (mahdlah) seperti shalat, dsb., melainkan juga menjadikannya sebagai sarana melakukan pemberdayaan umat. Pada masa Rasulullah SAW, masjid juga dijadikan tempat untuk pembinaan penyebaran agama Islam, tempat mengobati orang sakit, tempat mendamaikan orang-orang yang bertikai, tempat untuk mengatur strategi dalam latihan perang (militer), tempat untuk manyampaikan pengumuman penting. Bahkan dalam masa keemasan Islam, "universitas itu ada di dalam masjid. Sekarang justru masjid yang di dalam universitas". Tegasnya, masjid dalam kerangka kehidupan umat Islam sebenarnya memiliki fungsi yang luas, termasuk sebagai tempat pengem-bangan kehidupan dan perubahan sosial umat.

Apa yang disampaikan Nazarudin Umar tersebut tentunya dapat menjadi acuan pengembagan peran dan fungsi masjid secara holistik (menyeluruh). Dan hal ini dilakukan dengan beradaptasi dengan perkembagan ilmu pengetahuan dan teknologi guna mewujudkan masyarakat yang berdaya dan mandiri.

Pengembangan peran dan fungsi masjid secara holistik terasa semakin dibutuhkan mengingat semakin menyempitnya peran dan fungsi masjid sekarang ini. Ketika sebagaian besar masjid kini bergeser dari peran-peran historis dalam konteks perubahan sosial kemasyarakatan menuju bentuk penyeleng-gara kegiatan ibadah murni berupa shalat lima waktu, maka peran-peran yang bersifat sosial mengecil dan hanya beberapa masjid tertentu yang mencoba membangun sinergi dengan masyarakat dalam pemberdayaan potensi yang

${ }^{3}$ Asmawati, Pemberdayaan Fungsi Masjid Raya Darussasalm, Jurnal Studi Agama dan Masyarakat Vol. 10 No. 2 Desember 2013, 65.

Vol. 1 No. 1, April 2019 
ada. Pada perkembanganya, masjid lebih berfokus semata-mata sebagai penyelenggara ritual keagamaan. Padahal masjid memiliki posisi sentral dalam menggerakkan masyarakat dalam isu-isu yang terkait dengan pembengunan bangsa. Selain konsep peran, kredibilitas masjid hingga saat ini masih memiliki trust (kepercayaan) sebagai lembaga sentral bagi kehidupan keagama-an masyarakat dan sekitarnya.

Kontowijoyo menyatakan keprihatinannya dalam bukunya "Muslim Tanpa Masjid" ia mengkritisi pandangan bahwa masjid dianggap menghambat kemajuan pembangunan. Generasi muslim lebih suka mengidentikkan dirinya dengan masjid dan umat. Diperlukan integrasi substantif yang mempertemukan antara ilmu keislaman dengan ilmu sosial budaya dan lainnya. Di satu sisi umat membutuhkan masjid untuk mengespresikan citarasa keagamaan (taste of religious), di lain sisi masjid membutuhkan umat untuk memakmurkannya, sehingga terwujud simbiose mutualistik. ${ }^{4}$

\section{Peran Masjid}

a. Peran ruhaniyah masjid

Peran masjid yang paling utama adalah untuk menmemotivasi dan membangkitkan kekuatan ruhanyah dan imam, sebaliknya, jika kita merenungkan tentang peran tempat-tempat peribadatan agama lain, kita lihat bahwa tempat-tempat tersebut merupakan tempat dilakukannya perbuatan yang tercela. Karna masjid sangat berbeda, suasana yang berlaku dalam masjid karna mendorong untuk diamalkannya ibadah dan shalat,islam benar-benar membasmi perbuatan yang hina, seperti sebelum islam datang orang-orang arab biasanya bertwaf di ka'bah dalam keadaan telanjang bulat sebagai suatu ibadah, dan hal ini dilakukan secara bersama-sama oleh laki-laki dan perempuan.

Di dalam islam juga kita bisa beribadah dimana pun tempat asalkan tempat itu bersih dan suci, islam juga mengajar kan kita kita untuk bertutur yang sopan, dan menghindari perkataan yang keji. Islam memerintahkan para pemeluknya untuk shalat

4 A. Bachrun Rifa'i \& Moch. Fakhruroji, Manajemen Masjid Mengoptimalkan Fungsi Sosial Ekonomi Masjid (Bandung: Benang Merah Press, 2005), 97.

${ }^{5}$ Suprianto Abdullah, Peran Dan Fungsi Masjid (Yogyakarta: Cahaya hikmah:2003), hal: 5

$$
\text { Vol. } 1 \text { No. 1, April } 2019
$$


lima kali sehari semalam di mesjid, sehingga aktifitas keduniaan mereka di sesuaikan dengan shalat lima waktu di mesjid.

b. Masjid sebagai pusat kebudayaan

Peran mesjid yang terpenting dalam masyarakat juga untuk menghidupkan kebudayaan yang ada, kebudayaan islam meliputi setiap bidang kehidupan, dan ia mencerminkan cara kehidupan islam yang lengkap, dan memiliki hubungan yang khusus dan mendasar dengan pengetahuan yang muncul sejak lahirnya islam. ${ }^{6}$ Budaya-budaya yang dimaksud di sini yakni seperti memiliki madrasah-madrasah unruk anak-anak menuntut ilmu seperti al-Quran dan hadits. Jadi kita harus bisa memahami budaya yang ada dalam agama kita, jangan lah kita terlalu larut dalam budaya barat yang hanya akan membawa kita kedalam lembah kesesatan.

c. Peran masjid dalam bidang sosial

Dalam bidang sosial peran masjid tentu begitu penting, dengan adanya masjid didekat kita maka akan lebih memudahkan kita untuk melaksanakan shalat lima waktu, dan kita akan tau waktu shalat lebih cepat karna adanya orang yang azan, dan yang lebih penting dengan masjid dekat dengan lingkungan kita itu membuat kita rajin untuk shalat jema'ah, karna pahala shalat jama'ah 27 derajat lebih mulia dari pada shalat sendiri. Dalam buku Suprianto Abdullah peran masjid dalam bidang sosial yakni semua urusan kemasyarakatan, baik yang menyangkut urusan pribadi maupun bersama akan dibicarakan di dalam masjid, dan segala keputusan akan diselesaikan semuanya didalam masjid.dengan keterangan diatas peran masjid dapat membuktikan bahwa dalam Islam urusan ruhani maupun dunia dan kebendaan saling terkait, dan adalah sebagai pusatnya.

d. Peran masjid dalam bidang politik

Dalam bidang politik yang dimainkan umat islam yang shalih dan taat boleh dikatakan bahwa politik adalah hal yang terlarang, karna bagaimana pun politik adalah alat untuk mencapai tujuan yang banyak mengandung arti keji, seperti kita lihat pada saat ini politik hanya lah sebuah kebohongan untuk mencapai sebuah kemakmuran,

\footnotetext{
${ }^{6}$ Ibid., hlm. 8.
}

Vol. 1 No. 1, April 2019 
yang belum tentu lama untuk kita nikmati, apa gunanya kita bahagia dalam kebohongan. Saat politik seakan saama dengan korupsi, tipu daya, dan haus akan sebuah kekuasaan.

Sesungguhnnya politik yang diterapkan dalam islam adalah politik untuk menyeru manusia agar mereka dapat berserah diri secara mutlak kepada allah, dan menolak secara mutlak hal-hal yang bertentangan dengan kehendak allah dan agar saling menjaga hubungan yang selaras dengan sesama manusia.

\section{Remaja Masjid}

Remaja Masjid adalah perkumpulan pemuda masjid yang melakukan aktivitas sosial dan ibadah di lingkungan masjid.Hal ini sangat perlu dan mutlak keberadaannya dalam menjamin estafet makmurnya suatu masjid sehingga fungsi dinamika masjid itu sendiri dapat di pertahankan kelangengannya.

Pembagian tugas dan wewenang dalam remaja masjid termasuk dalam golongan organisasi yang menggunakan konsep islam dengan menerapkan asas musyawarah,mufakat dan amal jama'i(gotong royong) dalam segenap aktivitasnya.

Remaja masjid sebagai agen setrategis dalam pemberdayaan umat perlu dibekali keilmuan dan ketrampilan yang di butuhkan,misalnya para aktivis remaja masjid juga perlu menekuni pengetahuan jurnalistik dan kewirausahaan.Hal itu penting untuk menguatkan dakwah dan pemberdayaan umat.Dua pengetahuan itu dapat menjadi sarana dakwah,maupun peningkatan SDM Remaja masjid sehingga mampu mandiri.

Dalam buku panduan remaja masjid dijelaskan bahwa remaja masjid adalah sekelompok remaja atau pemuda yang berkumpul di masjid dan melakukan kegiatankegiatan yang ditujukan untuk memakmurkan masjid. ${ }^{7}$ Mengingat memakmurkan masjid adalah membentuk jama'ah atau menjadikan masjid yang penuh jama'ah dengan kegiatankegiatan keagamaan yang diselenggarakan untuk mengayomi, memelihara, memikirkan, dan mengembangkan jama'ah dan masyarakat lingkungan dengan program yang bermanfaat.

\section{HASIL DAMPINGAN}

Oleh karenanya tim dan narasumber pendamping mencari model kegiatan untuk menyampaikan beberapa materi yang menjadi realitas kebutuhan remaja masjid

\footnotetext{
${ }^{7}$ Umar jaeni.dkk, Panduan Remaja Masjid, (Surabaya : CV. Alfa Surya Grafika, 2003). h. 4 
Baiturrahman desa Bayeman kec. ARJASA kab. Situbondo keagamaan masyarakat pesisir yang antara lain:

\section{Peltihan ESQ}

ESQ adalah sebuah singkatan dari Emotional Spiritual Quotient yang merupakan gabungan EQ (Emotional Quotients) dan SQ (Spiritual Quotients), yaitu penggabungan antara pengendalian kecerdasan emosi dan spiritual.

Pelatihan ESQ adalah pelatihan kepemimpinan dan pengembangan kepribadian dengan tujuan membentuk karakter tangguh yang memadukan konsep kecerdasan intelektual (IQ) yang berfunsi “What I Think” (apa yang saya pikirkan) untuk mengelola fisik atau materi, kecerdasan emosional (EQ) yang berfungsi "What I Fell" (apa yang saya rasakan) untuk mengelola kekayaan sosial, dan kecerdasan spiritual (SQ) yang berfungsi "Who am I" (siapa saya) untuk mengelola kekayaan spiritual secara terintegrasi dan transendental. Konsep yang ditawarkan oleh Ary Ginanjar Agustian tentang membangun Emotional Spiritual Quotient (ESQ) berdasarkan pada 6 Rukun Iman dan 5 Rukun Islam, yang dapat dirangkum sebagai berikut :

a. Proses penjernihan pikiran (Zero Mind Process).

Pada tahap ini terjadi proses pembebasan pikiran dari belenggu-belenggu menuju pada suatu pikiran yang fitrah (God Spot), serta perlu diperhatikan kemampuan mengendalikan hati dan pikiran yang fitrah. Langkah ini dilakukan agar pikiran manusia terbebas dari paradigm salah yang akan membatasi pikiran. Hasil akhir yang diharapkan dari porses ini adalah lahirnya alam berfikir jernih dan suci atau fitrah, yaitu krmbali pada hati dan pikiran yang bersifat merdeka serta bebas. Dan ini merupakan tahap titik tolah dari kecerdasan emosi dan spiritual.

b. Pembangunan mental (Mental Building).

Melalui enam prinsip yang didasarkan pada Rukun Iman:

1) Iman kepada Allah sebagai pegangan dalam hidup, sehingga timbul rasa aman dan ketenangan yang akan menjernihkan pikiran sekaligus memberikan kesiapan mental untuk menghadapi perubahan-perubahan yang terjadi. 
2) Iman kepada Malaikat (Prinsip malaikat), yaitu memiliki integritas, loyalitas dan kebiasaan member sehingga selalu dipercaya oleh orang lain

3) Iman kepada Rasul (Prinsip kepemimpinan), yang akan menjadikan seseorang pemimpin yang berpengaruh

4) Iman kepada Al-Qur'an, (Kitab Allah), menyadari arti pentingnya prinsip pembelajaran yang akan mendorong kepada suatu kemajuan

5) Iman kepada hari Kiamat, yaitu mempunyai prinsip masa depan sehingga seseorang akan memiliki visi dalam hidupnya.

6) Iman kepada Takdir, yaitu memiliki prinsip keteraturan sehingga tercipta suatu system dalam satu kesatuan tauhid atau prinsip dalam berfikir.

c. Menciptakan ketangguhan pribadi (Personal Strength) dan ketangguhan social (Social Strength)

Melalui prinsip 5 Rukun Islam, yaitu sebagai berikut :

1) Penetapan misi, melalui penjabaran Syahadat karena makna Syahadat akan melatih membangun suatu keyakinan dalam berusaha, menicptakan daya dorong dalam mencapai suatu tujuan, membangkitkan keberanian dan optimism sekaligus menciptakan ketenangan batin dalam menjalankan misi hidup.

2) Pembangunan karakter yang dilambangkan dengan shalat. Shalat adalah suatu metode relaksasi untuk menjaga kesadaran diri agar tetap memiliki cara berfikir yang fitrah, serta metode yang dapat meningkatkan kecerdasan emosional dan spiritual secara terus menerus mengasah serta mempelajari ESQ yang diperoleh dari Rukun Iman.

3) Pengendalian diri (Self Controlling) yang dapat dilatih melalui puasa. Puasa adalah metode pelatihan untuk pengendalian diri dan memelihara fitrah diri.

4) Zakat merupakan suatu upaya Srtategic Collaboration sebagai langkah nyata untuk membangun suatu landasan yang kokoh guna membangun sebuah sinergi yang kuat, yaitu berlandaskan sikap empati, kepercayaan, sikap kooperatif dan keterbukaan, serta kredibilitas. 
5) Haji merupakan total action dan transformasi prinsip dan langkah secara total. Selain itu, haji adalah persiapan fisik dan mental dalam menghadapi berbagai tantangan masa depan.

2. Latihan Kepemimpinan Dasar Remaja Masjid Baiturrahman

Latihan Dasar Kepemimpinan ( LDK) adalah sebuah pelatihan dasar tentang segala hal yang berkaitan dengan kepemimpinan. Pelatihan ini biasanya yang diberikan oleh Pengurus organisasi, baik untuk tingkat Sekolah Menengah Pertama maupun Sekolah Menengah Atas (untuk Latihan Dasar Kepemimpinan (LDK) maupun organisasi kepemudaan lainnya. Pelatihan dasar yang diberikan ini bertujuan untuk memberikan bekal kepemimpinan kepada remaja masjid Baiturrahman yang nantinya akan menjadi pemimpin dari dalam organisasi Remaja Masjid Baiturrahman Bayeman Arjasa.

Latihan Dasar Kepemimpinan (LDK) biasanya diberikan dalam 2 bagian yaitu Latihan Dasar Kepemimpinan (LDK) Fisik dan Latihan Dasar Kepemimpinan (LDK) Mental. Pemberian materi dari kedua jenis LDK ini biasanya diberikan di waktu dan tempat yang berbeda. Untuk Latihan Dasar Kepemimpinan (LDK) Mental.

Dalam Latihan Dasar Kepemimpinan (LDK) Fisik ini peserta dituntut untuk memiliki kedisiplinan yang tinggi, terlebih selama mengikuti 2 hari Latihan Dasar Kepemimpinan (LDK). Beberapa peraturan yang pada umumnya diterapkan dalam Latihan Dasar Kepemimpinan (LDK) ialah: Selama pelaksanaan Latihan Dasar Kepemimpinan (LDK), peserta harus hadir di tempat tepat waktu.

Kebersamaan ialah hal yang amat diperhatikan selama pelaksanaan Latihan Dasar Kepemimpinan (LDK). Jika ada 1 peserta saja yang tidak membawa air minum, saputangan, topi, ataupun atribut-atribut lainnya yang telah ditetapkan, maka seluruh pesertalah yang akan menanggung hukumannya,Setiap peserta wajib mematuhi seluruh peraturan dan perintah yang diberikan oleh tim pemberi Latihan Dasar Kepemimpinan (LDK). 
Jika tidak, maka kepadanya akan diberikan hukuman, dan kebersamaan juga diterapkan apabila ada salah satu peserta Latihan Dasar Kepemimpinan (LDK) yang melakukan kesalahan.Hukuman dalam Latihan Dasar Kepemimpinan (LDK) Fisik biasanya berupa push-up untuk pria atau scott jump untuk wanita. Jumlahnya tergantung perintah dari pemberi Latihan Dasar Kepemimpinan (LDK).

\section{KESIMPULAN}

Dari hasil program Pengabdian pada Masyarakat ini, telah mengalami peningkatan. Peningkatan dapat terlihat dalam bentuk pelaksanaan program pendampingan dengan perubahan yang terjadi pada Remaja Masjid Bayeman Arjasa Situbondo.

\section{DAFTAR REFERENSI}

Mufidah Ch, dkk, Menjadi Sejabtera \& Mandiri Bersama Posdaya Masjid Kabupaten Malang, LP2MUIN Maling Press, 2014

Ahmad Sarwono, Masjid Jantung Masyarakat, Yogyakarta: Izzan Pustaka, 2003

Asmawati, Pemberdayaan Fungsi Masjid Raya Darussasalm, Jurnal Studi Agama dan Masyarakat Vol. 10 No. 2 Desember 2013

A. Bachrun Rifa'i \& Moch. Fakhruroji, Manajemen Masjid Mengoptimalkan Fungsi Sosial Ekonomi Masjid, Bandung: Benang Merah Press, 2005

Suprianto Abdullah, Peran Dan Fungsi Masjid, Yogyakarta: Cahaya Hikmah: 2003

Umar jaeni.dkk, Panduan Remaja Masjid, Surabaya : CV. Alfa Surya Grafika, 2003 